\title{
EFEKTIVITAS KOMUNIKASI ANTARPRIBADI DALAM MENCEGAH TINDAK KEKERASAN TERHADAP ANAK
}

\author{
Rini Rinawati ${ }^{1}$, Dedeh Fardiah ${ }^{2}$ \\ ${ }^{1,2}$ Fakultas Ilmu Komunikasi, Universitas Islam Bandung \\ Jl. Taman Sari No. 1 Bandung \\ No. Telp./HP: ${ }^{1} 0816617761,{ }^{2} 08122333753$ \\ E-mail: ${ }^{1}$ nierinirinawati66@gmail.com, ${ }^{2}$ dedehfardiah@gmail.com
}

Naskah diterima tanggal 5 Februari 2016, direvisi tanggal 27 Mei 2016, disetujui tanggal 20 Juni 2016

\section{EFFECTIVENESS OF INTERPERSONAL COMMUNICATION IN THE PREVENTION OF VIOLENCE AGAINST CHILDREN}

\begin{abstract}
Many children have become violence victim, not receive affection, protected including not attending school. Some of effort in preventing from violence is starting from the family. Therefore, this study is aimed for the effectiveness of interpersonal communication that is conducted by the parents with children in Bandung city, in order to prevent the violence against children. The case study used in this research, on the grounds that every area is different to each other because it certainly has a different culture. The respondent sample that we made a survey is 100 people. Results showed that parents in Bandung city are doing most of openness in communicating with their children, particularly related to violence that might exist in the child's environment. In addition, they have a positive attitude towards the association of children. Empathy in children is showing from their parents in order to prevent from violence. Equality in family is done by their parents in Bandung city to open the space for child participation, so that the children will open to their parents for asking something or to tell a various things.
\end{abstract}

Keywords: communication, children, violence.

\begin{abstract}
Abstrak. Banyak anak yang menjadi korban kekerasan, tidak menerima rasa sayang, dilindungi, termasuk juga tidak bersekolah. Salah satu upaya dalam mencegah tindakan kekerasan terhadap anak dimulai dari keluarga. Oleh karena itu penelitian ini bertujuan melihat efektivitas komunikasi antarpribadi yang dilakukan oleh orangtua dengan anak di Kota Bandung dalam rangka mencegah kekerasan terhadap anak. Studi kasus digunakan pada penelitian ini, dengan alasan bahwa setiap daerah berbeda satu sama lain karena tentunya memiliki budaya yang berbeda. Responden penelitian berjumlah 100 orang. Hasil penelitian menunjukkan bahwa orangtua di Kota Bandung sebagian besar melakukan keterbukaan dalam berkomunikasi dengan anak, khususnya berkaitan dengan kekerasan yang mungkin ada di lingkungan anak. Selain itu mereka memiliki sikap positif terhadap pergaulan anak. Rasa empati pada anak juga ditunjukkan orangtua dalam mencegah tindak kekerasan pada anak. Kesetaraan dalam keluarga juga dilakukan oleh orangtua di Kota Bandung untuk membuka ruang partisipasi anak, sehingga anak akan terbuka pada orangtua untuk bercerita berbagai hal.
\end{abstract}

Kata kunci: komunikasi, anak, kekerasan. 


\section{PENDAHULUAN}

Anak menjadi harapan bangsa. Seorang anak merupakan tumpuan harapan orangtua untuk menjadi penerus yang membanggakan orangtua, masyarakat, dan bangsa. Kondisi anak merupakan cermin kondisi bangsa di masa depan. Seorang anak memunyai hak dasar yang harus dipenuhi oleh orangtuanya yaitu hak hidup, hak tumbuh kembang, hak perlindungan, dan hak partisipasi. Dalam kenyataannya kondisi anak-anak tidak sesuai dengan harapan dan hak-haknya, bahkan mengalami kekerasan. Saat ini masyarakat sering dikagetkan dengan berita kekerasan yang dialami oleh anak-anak.

Maraknya kasus kekerasan pada anak sejak beberapa tahun ini seolah membalikkan pendapat bahwa anak perlu dilindungi. Jawa Barat menempati urutan ketiga dalam kasus kekerasan tertinggi di Indonesia, yaitu sebanyak 38\% artinya 6.510 .000 kasus ada di Jawa Barat (Perdana, 2013). Dengan demikian kondisi anak-anak di Jawa Barat sendiri banyak menjadi korban kekerasan. Bahkan di Jawa Barat sendiri kasus "Emon" membuat heboh rakyat Indonesia dengan korban kekerasan yang fantastis yaitu di atas 100 orang. Kota Bandung menjadi kota yang tertinggi tingkat kekerasannya di Jawa Barat. Data yang disampaikan oleh Ketua P2TP2A Netty Prasetiyani tahun 2016 Jawa Barat menyatakan: "Bandung Raya menjadi daerah yang paling sering terjadi kasus kekerasan seksual dan fisik terhadap perempuan dan anak di wilayah Provinsi Jawa Barat" (Anon, 2015).

Data yang ditemukan dari lembaga Pusat Pelayanan Terpadu Pemberdayaan Perempuan dan Perlindungan Anak (P2TP2A) Kota Bandung Tahun 2016 memerlihatkan bahwa terdapat peningkatan kasus kekerasan pada anak dari 2014 sampai 2015. Kekerasan pada anak tahun 2015 yang terjadi di Kota Bandung sebanyak 100 kasus, dan tahun 2015 sebanyak 120 kasus. Sementara itu kasus yang sedang ditangani tahun 2016 sampai dengan bulan Mei adalah sebanyak 36 kasus (Anon, 2015).
Kekerasan pada anak ternyata dilakukan oleh orang-orang yang ada di sekelilingnya. Hampir rata-rata pelaku kekerasan pada anak adalah orang-orang yang seharusnya melindungi anak. Pelaku kekerasan tersebut seperti tetangga, kakak asuh atau kakak sepermainan, keluarga dekat seperti paman, bahkan terdapat pelaku kekerasan seperti guru yang seharusnya menjadi teladan. Pelaku kekerasan lainnya yang mencengangkan adalah kakak kandung bahkan ayah kandung yang seharusnya merupakan orang-orang yang paling melindungi anak.

Salah satu faktor yang mendorong kekerasan pada anak adalah kurangnya komunikasi dalam keluarga. Orangtua yang sibuk dan juga anak yang sama-sama sibuk menyebabkan kurangnya intensitas komunikasi antara orangtua dan anak. Hal ini menyebabkan anak yang sedang mengalami permasalahan dalam tumbuh kembangnya banyak mencari teman curhat di luar. Inilah yang merupakan salah satu pendorong terjadinya kekerasan pada anak. Oleh karena itu menarik untuk mengkaji komunikasi antarpribadi yang dilakukan orangtua dengan anak-anaknya dalam rangka mencegah kekerasan yang terjadi pada anak.

Dari latar belakang tersebut, maka permasalahan yang dikaji adalah: "Bagaimana komunikasi antarpribadi dilakukan orangtua terhadap anak dalam mencegah tindak kekerasan?". Dari rumusan masalah tersebut pertanyaan penelitian yang dikemukakan adalah:

1. Bagaimana intensitas komunikasi orangtua dengan anak dapat mencegah tindak kekerasan pada anak?;

2. Bagaimana keterbukaan orangtua dengan anak untuk mencegah kekerasan pada anak?;

3. Bagaimana empati orangtua terhadap anak dapat mencegah tindak kekerasan pada anak?;

4. Bagaimana sikap mendukung dan sikap positif orangtua terhadap anak dalam mencegah tindak kekerasan pada anak?; 
5. Bagaimana kesetaraan yang ditunjukkan orangtua terhadap anak dalam mencegah tindak kekerasan pada anak?.

\section{LANDASAN KONSEP}

\section{Komunikasi Antarpribadi dalam Keluarga}

Komunikasi antarpribadi dilakukan manusia untuk memenuhi berbagai kebutuhan dan penyelesaian masalah yang dihadapi. Komunikasi antarpribadi dijelaskan oleh DeVito (Liliweri, 2003) sebagai pengiriman pesan dari seseorang dan diterima oleh orang yang lain, atau sekelompok orang dengan efek dan umpan balik yang langsung. Sendjaja (dalam Bungin 2007) mendefinisikan komunikasi antarpribadi adalah komunikasi antar perorangan dan bersifat pribadi, baik yang terjadi secara langsung (tanpa medium) ataupun tidak langsung (melalui medium).

Dalam prosesnya komunikasi antarpribadi menurut Johnson (dalam Supratiknya 2010) akan membantu manusia untuk memeroleh kebahagiaan hidup. Oleh karena itu terdapat berbagai peranan komunikasi antarpribadi, yaitu:

1. Komunikasi antarpribadi membantu perkembangan intelektual dan sosial manusia.

2. Identitas dan jati diri manusia terbentuk dalam dan lewat komunikasi antarpribadi.

3. Dalam rangka memahami realitas di sekelilingnya dan menguji kesan (makna) tentang dunia maka manusia melakukan komunikasi antarpribadi.

4. Kesehatan mental manusia sebagian besar ditentukan oleh kualitas komunikasi atau hubungan dengan orang lain (komunikasi antarpribadi) khususnya dengan orang-orang yang merupakan tokoh yang signifikan (significant figures).

Komunikasi antarpribadi pada gilirannya dilakukan dalam keluarga. Lestari (2010) memahami bahwa keluarga sebagai kelompok yang mengembangkan keintiman melalui perilaku yang memunculkan rasa identitas sebagai keluarga berupa ikatan emosi, pengalaman historis, maupun cita-cita masa depan. Oleh karena itu komunikasi antarpribadi menjadi sarana pemunculan identitas keluarga tersebut. Komunikasi keluarga melalui kegiatan antarpribadi menurut DeVito dalam Liliweri (2003) mengandung ciri-ciri sebagai berikut:

1. Keterbukaan (openess), adanya saling menanggapi informasi yang diterima di dalam hubungan antarpribadi.

2. Empati (empathy), adalah upaya merasakan apa yang dirasakan orang lain.

3. Dukungan (supportiveness), situasi karena adanya keterbukaan untuk mendukung komunikasi berlangsung efektif.

4. Rasa positif (positiveness), perasaan positif yang dimiliki individu berkaitan dengan dirinya, serta mendorong orang lain lebih aktif berpartisipasi, dan menciptakan situasi komunikasi kondusif untuk interaksi yang efektif.

5. Kesetaraan atau kesamaan (equality), pengakuan bahwa kedua belah pihak menghargai, berguna, dan memunyai sesuatu yang penting untuk disumbangkan.

Komunikasi dalam keluarga menurut Fitzpatrick dalam Littlejohn dan Foss (2011) ditentukan oleh orientasi keluarga tersebut terhadap komunikasi dan tingkat kesesuaian di antara anggota keluarga. Keluarga yang memunyai orientasi percakapan tinggi, maka keluarga tersebut akan senang melakukan komunikasi sesama anggota keluarga, yang ditandai dengan frekuensi komunikasi yang tinggi. Sementara, keluarga yang memiliki orientasi percakapan rendah, maka tidak sering melakukan komunikasi dengan sesama anggota keluarga.

Pada orientasi kesesuaian, keluarga yang memiliki orientasi kesesuaian tinggi, maka keluarga tersebut akan berjalan berdampingan, dalam hal ini orangtua sebagai pemimpinnya. Selain itu pada keluarga dengan orientasi kesesuaian yang tinggi ini, kebersamaan menjadi hal yang diutamakan. Sementara itu, keluarga dengan orientasi kesesuaian yang rendah, maka keluarga 
cenderung individualis, karena anggota keluarga tidak mengutamakan kebersamaan. Dalam keluarga yang orientasi kesesuaiannya rendah anggota keluarga akan lebih mementingkan sendiri-sendiri.

Komunikasi antarpribadi yang dilakukan dalam keluarga sangat berperan terhadap kehidupan anak. Hal ini disampaikan oleh Abriyoso et al., (2012) melalui penelitian yang dilakukannya. Abriyoso menemukan bahwa komunikasi antarpribadi khususnya yang dilakukan oleh orangtua dapat membantu memotivasi anak dalam belajar di sekolah. Komunikasi antarpribadi lebih jauh berperan dalam mencegah konflik yang terjadi antarremaja dijelaskan oleh Aini (2014). Konflik yang terjadi di kalangan anak-anak yang berusia remaja menunjukkan bahwa melalui pendekatan komunikasi antarpribadi yang dilakukan dengan bantuan pihak ketiga dalam memertemukan pihak yang berkonflik maka pengelolaan konflik dapat dilakukan. Konflik yang terjadi pada gilirannya bisa diselesaikan.

Setyowati (2005) menjelaskan bahwa kepribadian dan sifat-sifat anak terungkap melalui mekanisme hidup dalam keluarga. Keluarga merupakan faktor penentu, oleh karena itu komunikasi keluarga yang efektif tidak hanya menyangkut berapa kali komunikasi dilakukan, melainkan bagaimana komunikasi itu dilakukan. Dalam hal ini diperlukan adanya keterbukaan, empati, saling percaya, kejujuran, dan sikap suportif. Komunikasi antarpribadi orangtua dan anak dengan demikian sangat penting bagi tumbuh kembang anak.

Selanjutnya komunikasi antarpribadi yang dilakukan dalam sebuah keluarga akan mengikuti sebuah pola komunikasi. Fitzpatrick (dalam Littlejohn dan Foss 2011) menjelaskan bahwa ada empat pola komunikasi keluarga yang umum dilakukan, yaitu :

1. Pola Komunikasi Persamaan (Equality Pattern). Dalam pola ini, tiap individu berbagi hak yang sama dalam kesempatan berkomunikasi. Peran tiap orang dijalankan secara merata. Komunikasi berjalan dengan jujur, terbuka, langsung, dan bebas dari pembagian kekuasaan.

2. Pola Komunikasi Seimbang Terpisah (Balance Split Pattern). Kesetaraan hubungan tetap terjaga, namun dalam pola ini tiap orang memiliki daerah kekuasaan yang berbeda dari yang lainnya. Tiap orang dilihat sebagai ahli dalam bidang yang berbeda.

3. Pola Komunikasi Tak Seimbang Terpisah (Unbalanced Split Pattern). Dalam pola ini satu orang mendominasi, satu orang dianggap sebagai ahli lebih dari yang lainnya. Satu orang inilah yang memegang kontrol, seseorang ini biasanya memiliki kecerdasan intelektual lebih tinggi, lebih bijaksana, atau berpenghasilan lebih tinggi. Anggota keluarga yang lain berkompensasi dengan cara tunduk pada seseorang tersebut, membiarkan orang yang mendominasi itu untuk memenangkan argumen dan pengambilan keputusan sendiri.

4. Pola Komunikasi Monopoli (Monopoly Pattern). Satu orang dipandang sebagai pemegang kekuasaan. Satu orang ini lebih bersifat memberi perintah daripada berkomunikasi. Ia memiliki hak penuh untuk mengambil keputusan sehingga jarang atau tidak pernah bertanya atau meminta pendapat dari orang lain.

\section{Tindak Kekerasan terhadap Anak}

Kekerasan pada anak yang sering terjadi menyebabkan perlunya undangundang untuk melindungi anak-anak. Peraturan tentang perlindungan anak dijelaskan dalam Undang-Undang No. 35 Tahun 2014 Tentang Perubahan Atas Undang-Undang No. 23 Tahun 2002 Tentang Perlindungan Anak. Kekerasan dalam undang-undang tersebut dipahami sebagai setiap perbuatan pada anak yang berakibat timbulnya kesengsaraan atau penderitaan secara fisik, psikis, seksual, dan atau penelantaran termasuk ancaman untuk melakukan perbuatan, pemaksaan, atau perampasan kemerdekaan secara melawan hukum. 
Oleh karena itu, perlindungan pada anak sebagaimana dijelaskan dalam UndangUndang No. 35 Tahun 2014 merupakan kegiatan untuk menjamin dan melindungi anak dan hak-haknya agar dapat hidup, tumbuh kembang, dan berpartisipasi secara optimal sesuai harkat dan martabat secara kemanusiaan serta mendapat perlindungan dari kekerasan dan diskriminasi. Kekerasan pada anak dapat terjadi dalam berbagai jenis, yaitu:

1. Kekerasan fisik, yaitu kekerasan yang terjadi dengan akibat adanya kecatatan atau penderitaan secara fisik. Kekerasan ini dapat berupa pukulan, benturan, dan sebagainya.

2. Kekerasan psikis, yaitu kekerasan yang dilakukan di mana tidak berbentuk fisik namun melukai korban dari sisi mental atau psikologis.

3. Kekerasan seksual.

4. Penelantaran ekonomi.

\section{Teori Penentrasi Sosial}

Irwin Altman dan Dalmas Taylor pada tahun 1973 mengembangkan sebuah teori yang menfokuskan pada hubungan dalam berkomunikasi yang dilakukan berdasarkan adanya manfaat yang dirasakan para peserta komunikasi tersebut. Teori tersebut adalah Teori Penetrasi Sosial. Beberapa asumsi dasar dari Teori Penetrasi Sosial menurut Altman dan Taylor (dalam West dan Turner 2008) adalah:

1. Pembukaan diri adalah inti dari pengembangan hubungan.

2. Individu akan mengomunikasikan keintiman melalui lambang verbal dan non verbal.

3. Kepuasan dan stabilitas hubungan merupakan hasil dari proses penetrasi atau interaksi yang dilakukan.

Teori Penetrasi Sosial dapat dilakukan dalam sebuah keluarga dijelaskan oleh Sugijanto (2002) dalam kajiannya mengenai "Penetrasi Sosial pada Keluarga yang Berbeda secara Budaya" menjelaskan bahwa pasangan keluarga (suami-istri) yang berbeda secara budaya melakukan proses asimilasi melalui tahapan penetrasi sosial, yaitu
Orientasi dan Exploratory Affective Exchange. Pada tahapan-tahapan tersebut, masing-masing individu pasangan menikah atau suami-isteri yang berbeda budaya ini, melakukan pengungkapan diri (self disclosure). Dengan demikian semakin akrab seseorang dengan orang lain, maka semakin terbukalah ia dengan pasangannya.

Selanjutnya berkaitan dengan hubungan yang terjadi di antara individu dalam sebuah komunikasi, maka pengembangan hubungan akan mengikuti pada tahapan hubungan. Altman dan Taylor dalam West dan Turner (2008) menyatakan bahwa terdapat empat tahapan pengembangan hubungan yang dilakukan oleh orang-orang ketika berkomunikasi yaitu:

\section{Orientasi}

Pada awal hubungan seseorang hanya akan melakukan pertukaran informasi mengenai hal-hal yang klise bersifat umum saja, yang merefleksikan aspek superfisial seorang individu. Artinya, orang biasanya bertindak sesuai dengan cara yang dianggap baik oleh orang lain. Hal ini dilakukan dengan kehati-hatian agar tidak melanggar secara sosial. Pada tahap ini peserta akan melanjutkan hubungan bila mereka merasakan adanya manfaat dari hubungan yang dilakukan.

2. Pertukaran afektif eksploratif

Tahap pertukaran afektif eksploratif ini merupakan proses tahapan lanjutan yang dilakukan para pelaku hubungan untuk lebih dari sekedar mengungkapkan hal-hal yang bersifat umum sehingga hubungan semakin berkembang.

\section{Pertukaran afektif}

Tahap lanjutan dari sebuah hubungan yang dilakukan, karena hubungan menjadi semakin akrab atau intim, adalah ketika hubungan yang dilakukan tersebut memberikan manfaat yang dirasakan.

4. Pertukaran yang seimbang

Adalah tingkatan hubungan yang terjadi karena kedekatan yang tinggi dan memungkinkan mereka untuk saling memerkirakan tindakan dan respon dengan baik dalam sebuah hubungan. 


\section{METODE PENELITIAN}

Penelitian ini menggunakan metode deskriptif kualitatif untuk melihat keterbukaan, empati, dukungan, sikap positif, dan kesetaraan dalam komunikasi antarpribadi yang dilakukan orangtua dalam mencegah tindak kekerasan pada anak. Pemilihan metode deskriptif kualitatif dilakukan dengan dasar bahwa penelitian ini ingin mengungkap interpretasi mendalam terhadap temuan-temuan lapangan berdasarkan fakta yang ada mengenai komunikasi keluarga orangtua dalam mencegah tindak kekerasan pada anak. Penelitian kualitatif menurut Bogdan Taylor adalah salah satu prosedur penelitian yang menghasilkan data deskriptif berupa ucapan atau tulisan dan perilaku orang-orang yang diamati (Basrowi dan Sukidin, 2002).

Lokasi penelitian adalah Kota Bandung. Pemilihan Kota Bandung karena kota ini merupakan kota dengan angka kekerasan pada anak yang tinggi. Data dari P2TP2A Tahun 2016, Kota Bandung menjadi daerah yang paling sering terjadi kasus kekerasan khususnya kekerasan terhadap anak (Anon, 2015). Data dari Polrestabes Bandung menyatakan bahwa kepolisian sudah menangani sebanyak 199 kasus kekerasan seksual terhadap anak di bawah umur dari tahun 2014 sampai 2015. Angka tertinggi terjadi tahun 2015, dengan jumlah mencapai 91 kasus (Anon, 2015).

Informan penelitian adalah orangtua yang ada di Kota Bandung berjumlah 100 orang. Teknik kluster sampling digunakan untuk pemilihan informan didasarkan pada asumsi bahwa jumlah populasi yang banyak dan tersebar serta tidak adanya kerangka sampling jelas. Dari jumlah kecamatan yang ada di Kota Bandung sebanyak 30 kecamatan, maka dipilih berdasarkan kluster 4 (empat) kecamatan untuk menjadi lokasi penelitian, yaitu Kecamatan Panyileukan. Kecamatan Regol, Kecamatan Buah Batu, dan Kecamatan Bandung Wetan.

Teknik pengumpulan data yang dilakukan dalam penelitian ini menggunakan wawancara dan angket. Sementara itu analisis data dilakukan dengan menggunakan model analisis interaktif dari Miles dan Huberman (2007). Analisis data terdiri dari tiga komponen pokok yaitu reduksi data, sajian data, dan penarikan kesimpulan. Validitas data dilakukan dengan teknik triangulasi, yaitu teknik pemeriksaan, keabsahan data yang memanfaatkan sesuatu yang lain di luar data itu untuk keperluan pengecekan atau sebagai pembanding terhadap data tersebut (Moleong, 2001).

\section{HASIL PENELITIAN DAN PEMBAHASAN}

\section{Intensitas Komunikasi Orangtua dan Anak}

Hasil penelitian mengenai intensitas komunikasi yang berkaitan dengan frekuensi dan lamanya komunikasi ini mengisyaratkan bahwa orangtua di Kota Bandung terbagi oleh dua tipe yaitu orangtua yang intensitas komunikasinya cukup tinggi dan orangtua yang intensitas komunikasinya relatif rendah. Orangtua yang intensitas komunikasinya cukup tinggi dinamakan "Orangtua Komunikatif", dan orangtua yang intensitas komunikasinya dengan anak-anak kurang, dinamakan "Orangtua Non Komunikatif". Selanjutnya hasil penelitian tersebut memberikan arti bahwa tipe orangtua dalam melakukan komunikasi menjadi sebuah kondisi komunikasi keluarga secara umum. Keluarga yang komunikatif adalah keluarga yang memunyai orientasi untuk selalu meluangkan waktu atau melakukan komunikasi di dalam anggota keluarganya. Sementara, keluarga yang non komunikatif kurang berorientasi untuk senang atau sering melakukan komunikasi di antara anggota keluarga.

Intensitas komunikasi yang dilakukan orangtua di Kota Bandung menunjukkan bahwa proses orientasi sebagaimana dijelaskan dalam Teori Penetrasi Sosial sudah dilakukan orangtua terhadap anaknya untuk menumbuhkan kedekatan di antara keduanya. Teori Penetrasi Sosial menjelaskan bahwa tahapan orientasi dilakukan oleh orangtua 
melalui frekuensi komunikasi yang relatif tinggi dengan kuantitas komunikasi yang cukup lama. Hal ini akan memberikan manfaat yang dirasakan oleh keduanya sehingga kedua belah pihak akan melanjutkan pada tahap berikutnya.

Kondisi sebuah keluarga menurut Fitzpatrick (dalam Littlejohn dan Foss 2011) berkaitan dengan orientasi terhadap komunikasi. Fitzpatrick menjelaskan bahwa keluarga akan terbagi dalam dua kelompok orientasi terhadap komunikasi, yaitu orientasi percakapan (conversation orientation); kedua, orientasi kesesuaian (comformity orientation). Kedua orientasi ini pada gilirannya berkaitan dengan pola komunikasi dalam keluarga tersebut. Keluarga yang komunikatif adalah keluarga yang memunyai orientasi untuk selalu meluangkan waktu atau melakukan komunikasi di dalam anggota keluarganya. Sementara, keluarga yang non komunikatif kurang berorientasi untuk senang atau sering melakukan komunikasi di antara anggota keluarga.

\section{Keterbukaan Komunikasi Orangtua dan Anak}

Keterbukaan dalam komunikasi keluarga menjadi hal yang diperlukan untuk menjaga keharmonisan keluarga. Hasil penelitian menggambarkan bahwa keluarga di Kota Bandung terbagi dalam dua kelompok dalam hal keterbukaan komunikasinya dengan anggota keluarga. Sebagian besar orangtua memiliki keterbukaan dalam keluarga mengenai banyak hal, sementara sebagian orangtua yang lain kurang terbuka terhadap anaknya. Orangtua seringkali mendiskusikan berbagai persoalan dengan anak-anak mereka, di antaranya mengenai:

1. Pergaulan.

2. Batasan bagian tubuh yang boleh dijamah orang lain.

3. Penggunaan media untuk komunikasi dan hal lainnya termasuk dampak media.

4. Masalah pacaran.

Hasil temuan penelitian memberikan gambaran bahwa orangtua yang terbuka dalam berkomunikasi dengan anaknya, maka banyak hal yang bisa dibahas oleh orangtua demi melindungi anak dari kekerasan yang terjadi di lingkungan anak. Orangtua yang terbuka terhadap anak dengan demikian merupakan orangtua yang dengan sengaja meluangkan waktu untuk melakukan komunikasi dengan durasi komunikasi yang tinggi. Keterbukaan komunikasi yang dilakukan oleh orangtua dengan ini menandakan bahwa orangtua sangat peduli terhadap anak mereka termasuk pada masalah kekerasan yang saat ini sedang marak.

Orangtua yang memiliki keterbukaan dibanding dengan orangtua lain dengan demikian memiliki frekuensi komunikasi yang sangat tinggi dengan anak-anaknya. Adanya perbedaan yang terjadi dalam keterbukaan komunikasi pada keluarga di Kota Bandung disebabkan oleh berbagai faktor. Hasil penelitian menunjukkan salah satu penyebab perbedaan frekuensi komunikasi antarpribadi antara orangtua dan anak adalah faktor kesibukan orangtua dan anak.

Penelitian yang dilakukan menunjukkan bahwa orangtua di Kota Bandung memiliki kesibukan yang tinggi. Hal ini karena orangtua dalam arti ayah dan ibu merupakan pekerja kedua-duanya. Hasil penelitian menemukan bahwa terdapat $28 \%$ dari ibu-ibu merupakan pekerja, artinya memiliki kesibukan di wilayah publik selain menjadi ibu rumah tangga. Dari hasil penelitian yang menunjukkan banyaknya orangtua khususnya ibu sebagai ibu rumah tangga bukan berarti tidak memiliki kesibukan. Seringkali ibu rumah tangga juga memiliki berbagai kesibukan, seperti pengajian, arisan, dan sebagainya.

Namun demikian pada sebagian orangtua tidak menjadikan kesibukan mereka sebagai alasan untuk tidak melakukan komunikasi dengan anak. Hal ini terbukti dengan $95 \%$ orangtua di Kota Bandung selalu melakukan komunikasi dengan anak-anaknya, bahwa dari data penelitian diperoleh gambaran bahwa $68 \%$ orangtua melakukan komunikasi dengan durasi yang cukup lama dengan anak. Hal ini memberikan indikasi bahwa sebagian besar orangtua selalu melakukan komunikasi dengan anak-anaknya, 
hal ini dimaksudkan agar terdapat kedekatan hubungan antara orangtua dengan anak sebagaimana dijelaskan oleh Teori Penetrasi Sosial.

Temuan penelitian yang menjelaskan keterbukaan orangtua dalam komunikasi keluarga dengan anaknya melalui diskusi berbagai hal tentunya akan memberikan hasil berupa pengembangan hubungan yang lebih dekat dengan anak. Sesuai dengan penjelasan yang disampaikan oleh Altman dan Taylor (dalam West dan Turner 2008) bahwa pembukaan diri yang dilakukan orangtua adalah inti dari perkembangan hubungan. Selain itu orangtua mengomunikasi keintiman melalui lambang verbal dan non verbal khususnya berkaitan dengan upaya pencegahan kekerasan terjadi pada anaknya.

Hasil penelitian mengenai keterbukaan komunikasi yang dilakukan oleh orangtua bila dilihat dari pendapat Fitzpatrick dalam Littlejohn dan Foss (2011) menjelaskan adanya Pola Komunikasi Persamaan (Equality Pattern). Keluarga yang terbuka dalam berkomunikasi artinya mendiskusikan berbagai persoalan secara terbuka menganggap bahwa tiap individu atau anggota keluarga berbagi hak yang sama dalam kesempatan berkomunikasi. Peran tiap orang dijalankan secara merata. Komunikasi berjalan dengan jujur, terbuka, langsung, dan bebas dari pembagian kekuasaan. Semua orang memiliki hak yang sama dalam proses pengambilan keputusan. Keluarga mendapatkan kepuasan tertinggi bila ada kesetaraan.

\section{Empati Orangtua terhadap Anak dalam Berkomunikasi}

Empati adalah kemampuan untuk mengalami dan merespon perasaan orang lain. Oleh karena itu empati sangat dibutuhkan dalam kehidupan manusia khususnya dalam keluarga. Dengan empati akan membuat orangtua mengerti dan memahami apa yang dilakukan oleh anaknya. Dalam sebuah keluarga ketika orangtua memiliki empati pada anaknya, maka orangtua tersebut akan mengerti dan memahami kehidupan atau perkembangan anak-anaknya. Hasil penelitian mengenai empati dalam komunikasi yang dilakukan orangtua dengan anak-anaknya untuk mencegah tindakan kekerasan menunjukkan bahwa $80 \%$ dari orangtua memiliki empati ketika melakukan komunikasi.

Hasil penelitian mengenai empati yang ditunjukkan orangtua terhadap anak dalam mencegah tindak kekerasan memberikan arti bahwa orangtua di Kota Bandung terbagi dalam dua tipe yaitu orangtua yang memiliki empati terhadap anak dan orangtua yang kurang berempati pada anak. Orangtua yang berempati ditunjukkan dengan adanya pemahaman orangtua terhadap dunia anak dan perkembangannya. Empati orangtua selanjutnya ditunjukkan dengan cara memberikan informasi mengenai batasan dalam kehidupan yang harus dipahami anak. Selanjutnya juga orangtua bisa mendiskusikan dengan anak mengenai hal-hal yang dirasakan oleh anak. Rasa kasih sayang pada akhirnya ditunjukkan orangtua yang berempati pada masalah kekerasan yang ada di lingkungan anak.

Tahapan pertukaran afektif dan eksploratif sebagaimana dijelaskan dalam Teori Penetrasi Sosial ditampilkan oleh orangtua dengan cara empati yang ditunjukkan kepada anaknya, sehingga anak akan merasakan manfaat dari komunikasi yang dilakukan orangtua. Pada akhirnya dengan empati yang ditunjukkan oleh orangtua diharapkan anak akan lebih dekat dengan orangtua sehingga akan menghasilkan kedekatan anak kepada orangtua. Tujuan akhir dari pengembangan hubungan yang dilakukan oleh orangtua melalui rasa empati yang ditunjukkannya adalah anak menjadi terbuka pula dalam masalah pergaulan dengan teman-temannya, sehingga orangtua dapat memantau perkembangan anak untuk mencegah tindakan kekerasan.

\section{Sikap Mendukung Orangtua terhadap Anak}

Hubungan antarpribadi orangtua dan anak akan efektif apabila hubungan yang terjadi memiliki sikap mendukung di antara kedua belah pihak. Komunikasi yang terbuka 
dan empatik tidak dapat berlangsung dalam suasana yang tidak mendukung. Sikap mendukung, dapat orangtua tunjukkan melalui sikap yang muncul dalam komunikasi dengan anak, sebagai contoh tidak menghakimi atas apa yang dikeluhkan anak atau lakukan apabila hal yang mereka lakukan dianggap menyimpang atau kurang berkenan.

Temuan penelitian memerlihatkan bahwa orangtua terbagi dalam dua kelompok, yaitu orangtua yang memiliki sikap mendukung dan orangtua yang tidak mendukung terhadap apa yang dilakukan oleh anak dalam kehidupannya terutama pencegahan kekerasan yang ada di lingkungan anak. Temuan penelitian menggambarkan bahwa orangtua di Kota Bandung sangat tidak mendukung terhadap tindak kekerasan yang dilakukan oleh siapapun termasuk anaknya sendiri terhadap orang lain. Sementara itu juga orangtua tidak mendukung terhadap tindak kekerasan yang terjadi terhadap anak-anaknya. Komunikasi keluarga dengan demikian menjadi jalan bagi orangtua untuk memberikan pengertian kepada anak-anaknya mengenai maraknya kekerasan yang terjadi di Kota Bandung. Dalam komunikasi keluarga, orangtua memberikan pemahamanan mengenai batasan yang boleh dan tidak boleh dilakukan anak dalam pergaulan sehingga akan menghindarkan anak dari kemungkinan munculnya tindak kekerasan yang akan terjadi.

Adanya komunikasi yang dilakukan oleh orangtua sehingga memunculkan sikap mendukung terhadap pergaulan anak yang sehat dan tidak mendukung terhadap tindakan kekerasan yang dilakukan oleh anaknya maupun orang lain terhadap anaknya berkaitan dengan pendapat dari Supratiknya (2010) mengenai kebahagian. Menurut Supratiknya komunikasi antarpribadi sangat berperan dalam rangka menciptakan kebahagian hidup manusia.

\section{Sikap Positif Orangtua terhadap Anak}

Komunikasi antarpribadi akan harmonis jika seseorang memiliki sikap postif terhadap diri mereka sendiri dan orang lain. Selain itu, perasaan positif dalam komunikasi sangat penting untuk menciptakan interaksi yang efektif. Sikap positif yang ditunjukkan oleh orangtua terhadap anak sangat penting dalam rangka menghargai keberadaan dan pentingnya anak bagi orangtua. Temuan penelitian mengenai sikap positif orangtua memberikan gambaran bahwa orangtua di Kota Bandung memiliki sikap positif yang berbeda terhadap anaknya.

Hasil penelitian memberikan indikasi adanya tiga tipe sikap positif orangtua terhadap anaknya. Tipe pertama adalah orangtua yang memiliki sikap yang sangat positif terhadap anaknya. Tipe kedua adalah orangtua yang memiliki sikap positif sedangsedang saja terhadap anak dan tipe yang ketiga adalah orangtua yang memiliki sikap kurang positif terhadap anaknya.

Sikap positif yang ditunjukkan orangtua dalam komunikasi dengan anaknya berdasarkan hasil penelitian berkaitan dengan Teori Pelanggaran Harapan. Judee Burgoon (dalam Littlejohn and Foss, 2011) melalui teorinya menjelaskan mengenai jarak komunikasi yang dilakukan oleh anak baik dengan orangtuanya maupun dengan yang lain. Melalui teori ini hasil penelitian menjelaskan bahwa orangtua memunyai harapan mengenai jarak komunikasi anaknya dalam berkomunikasi dengan orang lain dalam pergaulan.

Adanya tiga tipe orangtua yang pada akhirnya ditemukan berkaitan dengan sikap positif terhadap anaknya tentunya dipengaruhi oleh kedekatan komunikasi secara sosial antara orangtua dan anaknya. Hasil temuan penelitian yang menjelaskan bahwa orangtua memiliki sikap sangat positif terhadap anaknya kemungkinan besar orangtua tersebut memunyai hubungan atau jarak komunikasi yang dekat dengan anaknya. Berbeda dengan orangtua yang kurang bersikap positif terhadap anaknya, kemungkinan didasari oleh tidak adanya kedekatan orangtua dengan anaknya, sehingga orangtua tidak mengetahui mengenai anaknya. Hal ini sesuai dengan tahapan pertukaran yang seimbang sebagaimana dijelaskan dalam Teori Penetrasi 
Sosial. Dalam hal ini tingkatan hubungan memunculkan kedekatan yang tinggi dan memungkinkan mereka untuk saling memperkirakan tindakan dan respon dengan baik dalam sebuah hubungan.

\section{Kesetaraan Orangtua dengan Anak dalam Komunikasi Keluarga}

Dalam berkomunikasi, pengakuan bahwa kedua pihak sama-sama bernilai dan berharga (kesetaraan) sangat penting. Pada komunikasi keluarga kesetaraan menjadi salah satu syarat untuk menciptakan keluarga yang harmonis. Namun demikian, kesetaraan tidak mengharuskan seseorang menerima dan menyetujui begitu saja semua perilaku orang lain, melainkan menerima dan memberikan "penghargaan positif tidak bersyarat".

Hasil penelitian menjelaskan bahwa orangtua di Kota Bandung sudah menerapkan kesetaraan dalam rumah tangganya antara orangtua dan anak-anaknya. Temuan penelitian ini memberikan penjelasan bahwa keluarga yang menerapkan kesetaraan memberikan kebebasan kepada anak-anaknya untuk bisa turut dalam memecahkan persoalan keluarga, juga memberikan kebebasan kepada anak-anaknya dalam mengemukakan pendapat atau masalah. Keluarga yang seperti ini dalam arti menerapkan kesetaraan juga tidak membedabedakan perlakukan pada anak laki-laki maupun anak perempuan. Bahkan dalam keluarga yang menerapkan kesetaraan sebuah aturan yang berlaku itu diterapkan untuk orangtua dan anak-anaknya. Gambaran hasil penelitian pada keluarga tersebut memberikan indikasi bahwa keluarga tersebut sudah menerapkan pola demokratis dalam keluarga, dengan demikian keluarga tersebut bisa dinamakan "Keluarga Demokratis".

Keluarga yang tidak menerapkan kesetaraan memerlihatkan hal-hal yang sebaliknya dengan keluarga demokratis, yaitu mereka jarang mendiskusikan masalah yang ditemui dalam keluarga dengan anggota keluarga. Diskusi yang dilakukan mengenai masalah sering kali dilakukan oleh ayah dan ibu saja tanpa melibatkan anak-anaknya. Demikian pula keluarga ini menerapkan perbedaan perlakuan pada anak laki-laki dan anak perempuan. Hal ini dilakukan karena berdasarkan kebiasaan. Selain itu aturan yang berlaku juga ada perbedaan bagi orangtua dan anak-anak sesuai dengan porsinya masingmasing. Keluarga yang menggambarkan hasil penelitian dengan tidak menerapkan kesetaraan seperti ini adalah keluarga yang kurang demokratis.

Temuan penelitian yang menunjukkan adanya pola kesetaraan pada keluarga demokratis sesuai dengan pendapat dari Fitzpatrick (dalam Littlejohn Foss, 2011) yang termasuk pada tipe keluarga konsensus. Keluarga ini menerapkan pola Komunikasi Persamaan (Equality Pattern). Dalam pola ini, tiap individu berbagi hak yang sama dalam kesempatan berkomunikasi. Peran tiap orang dijalankan secara merata. Komunikasi berjalan dengan jujur, terbuka, langsung, dan bebas dari pembagian kekuasaan. Semua orang memiliki hak yang sama dalam proses pengambilan keputusan. Keluarga mendapatkan kepuasan tertinggi bila ada kesetaraan. Sementara temuan penelitian mengenai keluarga yang tidak demokratis bila dikaitkan dengan pendapat Fitzpatrick, maka keluarga tersebut menerapkan Pola Komunikasi Seimbang Terpisah (Balance Split Pattern). Kesetaraan hubungan tetap terjaga, namun dalam pola ini tiap orang memiliki daerah kekuasaan yang berbeda dari yang lainnya. Tiap orang dilihat sebagai ahli dalam bidang yang berbeda. Sebagai contoh, dalam keluarga normal/tradisional, suami dipercaya dalam urusan bisnis atau politik. Istri dipercaya untuk urusan perawatan anak dan memasak. Namun pembagian peran berdasarkan jenis kelamin ini masih bersifat fleksibel. Konflik yang terjadi dalam keluarga tidak dipandang sebagai ancaman karena tiap individu memiliki area masing-masing dan keahlian sendiri-sendiri.

\section{PENUTUP}

\section{Simpulan}

Keluarga di Kota Bandung memiliki keterbukaan yang tinggi dalam 
berkomunikasi sehingga meningkatkan kedekatan orangtua dengan anak. Keterbukaan orangtua dalam komunikasi antarpribadi dengan anak dilakukan dalam rangka mencegah kekerasan yang mungkin terjadi pada anak.

Orangtua memiliki empati yang cukup tinggi terhadap anak-anaknya, sehingga menyebabkan anak memiliki kedekatan dengan orangtuanya karena merasakan manfaat dari pengembangan komunikasi keluarga dan diharapkan akan mencegah kekerasan yang mungkin terjadi pada anak.

Orangtua cukup mendukung anakanaknya khususnya berkaitan dengan pergaulan yang sehat di lingkungan anakanaknya untuk mencegah tindak kekerasan.

Sikap positif ditunjukkan oleh orangtua terhadap anak-anaknya, sehingga anak-anak merasa nyaman melakukan komunikasi dengan orangtua. Hal ini membuat anak-anak terbuka terhadap orangtua dalam banyak hal, dan pada akhirnya diharapkan dapat mencegah tindak kekerasan pada anak.

Orangtua sudah cukup memiliki kesetaraan dalam berkomunikasi dengan anak-anaknya. Orangtua sering melibatkan anak-anaknya dalam pengambilan keputusan dan memecahkan berbagai persoalan keluarga yang dihadapi.

\section{DAFTAR PUSTAKA}

Abriyoso, O. J., Karimah, K. El and Benyamin, P. (2012). Hubungan Efektivitas Komunikasi Antarpribadi dalam Keluarga dengan Motivasi Belajar Anak di Sekolah. eJurnal Mahasiswa Universitas Padjadjaran, 1 (1).

Aini, R. (2014). Peran Komunikasi Antarpribadi Sebagai Pencegah Terjadinya Konflik Pada Hubungan Persahabatan Remaja di Samarinda. eJournal Ilmu Komunikasi, 2 (1), p.290-304. [Online]. Available at: http://ejohttp//ejournal.ilkom.fisipunmul.ac.id/site/?p=1267.

Anon. (2015). Kasus Kekerasan Seksual Terhadap Anak di Bandung Lebih Dominan Dibanding Kasus Anak Lainnya. [Online]. Available at: http://jabar.tribunnews.com/2016/05/12/kas us-kekerasan-seksual-terhadap-anak-di- bandung-lebih-dominan-dibanding-kasusanak-lainnya.

Basrowi and Sukidin. (2002). Metode Penelitian Perspektif Mikro: Grounded Theory, Fenomenologi, Etnometodologi, Etnografi, Dramaturgi, Interaksi Simbolik, Hermeneutik, Konstruksi Sosial, Analisis Wacana, dan Metodologi Refleksi. Surabaya: Insan Cendekia.

Bungin, B. (2007). Teori, paradigma, dan Diskursus Teknologi Komunikasi di Masyarakat (Sosiologi Komunikasi). Jakarta: Kencana.

Lestari, S. (2010). Psikologi Keluarga: Penanaman Nilai dan Penanganan Konflik dalam Keluarga. Prenada Media Group.

Liliweri, A. (2003). Perspektif Teoritis Komunikasi Antarpribadi; Suatu Pendekatan ke Arah Psikologi Sosial Komunikasi. Bandung: PT. Cipta Aditya Bakti.

Littlejohn, S. W. and Foss, K. A. (2011). Teori Komunikasi (pen. Mohammad Yusuf Hamdan). Jakarta: Salemba Humanika.

Miles, M. B. and Huberman, A. M. (2007). Analisis Data Kualitatif (pen. Tjetjep

Rohendi Rohidi). Jakarta: Penerbit Universitas Indonesia.

Moleong, J. (2001). Metodologi Penelitian Kualitatif. Bandung: PT. Remaja Rosda Karya.

Perdana, P. P. (2013). Kasus Kekerasan di Jabar, Ketiga Tertinggi di Indonesia. [Online]. Available at: http://sains.kompas.com/read/2013/12/04/2 155373/Kasus.Kekerasan.di.Jabar.Ketiga.T ertinggi.di.Indonesia. [Accessed: 24 September 2015].

Republik Indonesia. (2014). UU No 35/2014 tentang Perubahan atas Undang-undang No 23 Tahun 2002 tentang Perlindungan Anak. Republik Indonesia.

Setyowati, Y. (2005). Pola komunikasi keluarga dan perkembangan emosi anak (Studi kasus penerapan pola komunikasi keluarga dan pengaruhnya terhadap perkembangan emosi anak pada keluarga Jawa). Jurnal Ilmu Komunikasi, 2 (1), p.67-78.

Sugijanto, M. (2002). Penetrasi Sosial Pada Pasangan Menikah Berbeda Budaya (Studi Kasus Komunikasi Antar Budaya Perkawinan Campur Antara Etnis Jawa dengan Etnis Minangkabau di Jabotabek). Universitas Indonesia. 
Supratiknya, A. (2010). Komunikasi Antar Pribadi, Tinjauan Psikologis. Yogyakarta: Kanisius.

West, R. and Turner, L. (2008). Pengantar Teori Komunikasi: Analisis dan Aplikasi (Terj.
Maria Natalia Damayanti). Jakarta: Salemba Humanika. 